\title{
AKULtuRAsi BUdAYA SUNDA DAN JEPANG MELALUI PENGGUNAAN IGARI lOOK DALAM TATA RIAS SUNDA SIGER
}

\section{THE ACCULTURATION OF MODERN SUNDA SIGER COSMETIC TO JAPANESE IGARI MAKEUP}

\author{
Fauziah Ismi Desiana \\ Reiza D. Dienaputra
}

Program Studi Kajian Budaya, Fakultas Ilmu Budaya Universitas Padjadjaran Jln.Raya Bandung-Sumedang Km. 21. Jatinangor Kab. Sumedang 45363 Jawa Barat e-mail: fauziahismid94@gmail.com,reizaputra@unpad.ac.id

\begin{abstract}
Abstrak
Akulturasi budaya Jepang dan Sunda dalam bingkai tata rias Sunda Siger membuktikan bahwa tata rias tradisional dapat dikemas modern dalam balutan teknik Igari Look. Penelitian ini menggunakan metode kualitatif dengan pendekatan deskriptif. Pengumpulan data didapatkan dari wawancara dengan make-up artist yang menggunakan teknik make-up Igari Look dalam tata rias Sunda Siger dan aktif mengunggah hasil tata riasnya dalam sebuah portofolio di Instagram. Akulturasi kebudayaan Sunda dan Jepang dalam tata rias Sunda Siger merupakan bukti bahwa masyarakat Sunda terbuka dengan situasi multikultural. Keberadaan Igari Look dalam bingkai tata rias Sunda Siger pada hakikatnya bukan bertujuan untuk memarjinalkan makna filosofis dan historis dalam setiap unsur tata rias Sunda Siger, namun proses inovasi dari make-up artist ini perlu dimaknai sebagai sumbangsih untuk menghidupkan kembali tata rias tradisional agar lebih diminati oleh kaum muda.
\end{abstract}

Kata kunci: akulturasi, Jepang-Sunda, tata rias, Igari Look, Sunda Siger.

\section{Abstract}

Acculturation of Japanese and Sundanese culture in frame Sunda Siger cosmetology proves that traditional cosmetology can be filled with modern dressing in the Igari Look technique. This study uses qualitative methods using descriptive. Data collection was obtained from interviews with make-up artists who used the Igari Look make-up technique in the Sunda Siger makeup and actively uploaded the makeup results in a portfolio on Instagram. Acculturation of Sundanese and Japanese culture in Sundanese Siger makeup is proof that Sundanese society is open with multiculturalism. The existence of Igari Look in the Sunda Siger makeup frame in essence is not an agreement to marginalize philosophical and historical meanings in any Sundanese Siger makeup, the innovation process of this make-up artist needs to be interpreted as cleft of young people.

Keywords: acculturation, Japanese-Sundanese, cosmetology, Igari Look, Sunda Siger.

\section{A. PENDAHULUAN}

Sudah seyogyanya setiap pengantin selalu menginginkan dirinya tampil maksimal di pernikahannya. Terlebih bagi pengantin perempuan pasti menginginkan dirinya terlihat berbeda dan lebih cantik dari hari biasanya. Hal itulah yang menjadikan peran tata rias pengantin perempuan dinilai sebagai bagian penting dalam sebuah perhelatan pernikahan. Tata rias berfungsi sebagai "kekuatan untuk merubah wajah lebih berseri dan tampak istimewa dengan tetap memperhatikan 
kecantikan alami yang bersifat personal" (Andiyanto, 2010: 150).

Orang Sunda mengenal tata rias pengantin Sunda Siger yang memiliki ciri khas penggunaan Siger sebagai hiasan kepala pengantin perempuan. Siger adalah perhiasan kepala yang terbuat dari logam bermatakan batu-batuan. Siger ini dipasang melingkar. Bagian depannya dipasang di atas dahi, kemudian berturut-turut melingkari samping dan kepala (Departemen Pendidikan dan Kebudayaan, 1986: 24).

Adapun Tien Santoso (2010) dalam buku Tata Rias dan Busana Pengantin Seluruh Indonesia menjelaskan rias pengantin Sunda Siger sebagai "benang merah budaya Sunda yang sakral". Menurut kamus Basa Sunda RA Danadibrata, Siger ini diartikan sebagai mahkota untuk perhiasan di kepala pengantin. Ini menjadi simbol untuk seseorang yang melaksanakan upacara sakral, seperti pernikahan. Selain itu juga berarti kehormatan, meletakkan kearifan, serta sikap bijak sebagai hal pokok yang perlu dijunjung tinggi (Santoso:2010).

Makna simbolis yang terkandung pada Siger membuatnya lebih dari sekadar pemanis, namun mengandung makna filosofis yang sangat dalam yang harus dihayati guna mendapat kehidupan pernikahan yang harmonis. Dalam hal ini tata rias Sunda Siger dapat dikatakan sebagai suatu bentuk ekspresi dan penyampaian pesan moral yang tertuang dalam lingkaran kebudayaan Sunda yang berisi nilai-nilai luhur bagi kehidupan pernikahan sang pengantin.

Bridestory.com yakni market place online untuk keperluan pernikahan terbesar di Asia Tenggara mengumumkan survei bahwa konsep klasik tradisional adalah konsep perhelatan pernikahan yang paling banyak diusung pengantin di Indonesia di tahun 2017. Hal tersebut memperlihatkan bahwa bingkai kebudayaan tradisional dalam pernikahan sedang menjadi tren di tahun 2017 . Ramainya permintaan pengantin perempuan Sunda yang menginginkan dirinya dirias dalam balutan Sunda Siger tidak bisa dilepaskan dari kiprah para make-up artist yang senantiasa memberikan inspirasi tata rias Sunda Siger kepada para pengikutnya di Instagram.

Make-up artist dinilai mampu mengikuti kemajuan teknologi, karena mampu memadukan kemajuan teknologi dengan kebudayaan. Tata rias pada hakikatnya termasuk dalam bagian kebudayaan material yang "mengacu pada semua ciptaan masyarakat yang nyata, konkret" (Ismayanti, 2010: 154). Melalui unggahan portofolio make-up berupa foto, video dan caption (penjelasan singkat atau deskripsi yang menyertai foto atau video) yang menarik, membuat Instagram dijadikan make-up artist sebagai sarana referensi bagi calon pengantin perempuan dalam mencari inspirasi tema tata rias yang akan digunakan dalam hari pernikahannya. Sehingga tak jarang para make-up artist tersebut memiliki puluhan ribu followers (pengikut) di Instagram.

Seorang make-up artist dituntut untuk selalu menghasilkan signature (ciri khas) tata rias melalui ide-ide cemerlang dalam menciptakan karya tata rias yang inovatif, sehingga menjadi hal otentik yang diakui sebagai karyanya. Inovasi dapat menjadikan make-up artist tersebut sebagai seorang pelopor tren make-up. Melalui inovasi pula, seorang make-up artist dapat produktif menciptakan nuansa baru dan kekinian dalam dunia tata rias agar senantiasa menjadi inspirasi bagi make-up artist lainnya.

Tidak jarang sang make-up artist menamakan signature (ciri khas) tata rias yang mereka usung dengan sebutan unik. Salah satunya Nadia Sabrina (@nanathnadia) make-up artist dari tanah Sunda, menamai signature (ciri khas) tata

\footnotetext{
${ }^{1}$ https://www.bridestory.com/id/blog/2017indonesia-wedding-trends-report-by-bridestory diakses pada 27 Novermber 2017
} 
riasnya dengan sebutan blush-on demam manja yang diadopsi dari Igari Look. Nadia Sabrina (@nanathnadia) dinilai berhasil membawa kesan soft dan flawless dalam tata rias Sunda dengan teknik Igari Look.

Adanya akulturasi antara kebudayaan Sunda dan Jepang dalam dunia tata rias ini membuktikan bahwa tata rias tradisional dapat dikemas secara modern, apabila ada kemauan untuk melakukan inovasi agar menambah nilai estetika dari hasil tata rias. Kini Igari Look banyak diadopsi oleh make-up artist lainnya untuk mendapatkan tampilan pengantin perempuan Sunda Siger yang terkesan anggun dan segar.

Igari Look merupakan gaya make-up Jepang yang memfokuskan penggunaan warna merah muda dan merah untuk mewarnai bagian wajah dengan blush-on. Igari Look adalah tren tata rias yang diciptakan oleh seniman asal Jepang bernama Shinobi Igari ${ }^{2}$. Igari Look memberikan kesan merona pada bawah mata hingga pipi. Igari Look ini didapatkan dengan membubuhkan blushon dengan penggabungan warna pink dan orange pada pipi sampai ke atas mendekati ujung mata.

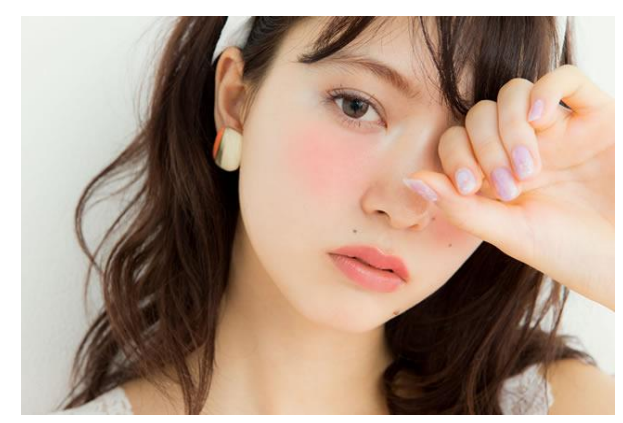

Gambar 1.

Contoh pengaplikasian Igari Look

Sumber : www. cewekbanget.grid.id

Tidak dapat dipungkiri bahwa saat ini Igari Look telah menjadi suatu teknik

\footnotetext{
${ }^{2}$ http://cewekbanget.grid.id/Fashion-AndBeauty/Tutorial-Igari-Makeup-Riasan-CuteYang-Hits-Banget-Di-Jepang diakses pada 2 Mei 2018 pukul 9:14 WIB.
}

make-up yang sering dipadukan dengan tata rias Sunda Siger. Dalam kerangka budaya, hal tersebut dapat digolongkan pada akulturasi antara tata rias Sunda Siger dan Igari Look dari Jepang. "Akulturasi merupakan wahana atau area dua kebudayaan bertemu, di mana masingmasing dapat menerima nilai bawaannya" (Sachari, 2007: 30).

Koentjaraningrat (1990: 253-254) menjelaskan akulturasi sebagai proses sosial yang timbul apabila sekelompok manusia dengan suatu kebudayaan tertentu dihadapkan pada unsur-unsur kebudayaan asing sehingga unsur-unsur asing itu lambat laun diterima dan diolah ke dalam kebudayaan sendiri, tanpa menyebabkan hilangnya kepribadian kebudayaan itu. Dalam tingkatan tertentu akulturasi akan menimbulkan dua komponen pilihan yaitu, melindungi kebudayaan dan mempelajari kebudayaan. Kedua komponen tersebut jarang dilakukan bersamaan secara sempurna, namun perlu dilakukan proses seleksi untuk memutuskan bagian mana yang akan dipertahankan dan bagian mana yang akan diubah.

Tata rias Siger Sunda yang keberadaannya dipengaruhi oleh budaya, legenda dan mitos, serta kondisi-historis masyarakat Pasundan telah berbaur dengan Igari Look yang notabenenya adalah tren pengaplikasian blush-on yang pertama kali dipopulerkan di Jepang. Hal tersebut dimaknai positif bagi para make-up artist lain yang turut serta menyemarakan tren Igari Look dalam tata rias Sunda Siger.

Dari pemaparan di atas, peneliti melihat adanya suatu akulturasi budaya antara tata rias Sunda Siger yang pada awalnya digunakan sebagai penanda identitas budaya Sunda, dengan Igari Look yang merupakan tren pengaplikasian blush-on yang pertama kali dipopulerkan di Jepang. Penelitian ini akan mengungkapkan bentuk akulturasi tata rias Sunda Siger yang mendapat pengaruh Igari Look? 


\section{B. METODE PENELITIAN}

Penelitian ini menggunakan metode kualitatif dengan pendekatan deskriptif. Penelitian kualitatif mencoba mengerti makna suatu kejadian atau peristiwa dengan mencoba berinteraksi dengan orang-orang dalam situasi/ fenomena tersebut (Yusuf.2017:328). Dalam penelitian ini peneliti melakukan interaksi berupa wawancara terstruktur dengan tiga informan yaitu Eviyawati, Mya dan Muthia. Ketiganya merupakan make-up artist yang sering menggunakan teknik make-up Igari Look dalam tata rias Sunda Siger. Mereka aktif mengunggah hasil tata riasnya di Instagram. Pendekatan deskriptif dipilih peneliti karena penelitian ini berusaha untuk menuturkan pemecahan masalah berdasarkan data yang telah dikumpulkan.

Teknik pengumpulan data dalam penelitian ini menggunakan teknik wawancara terstruktur yang merupakan wawancara yang "secara eksplisit penghimpunan instruksi kepada pewawancara yang mengelola kuisioner secara lisan" (Endraswara, 2006:166). Peneliti juga mengumpulkan data melalui studi pustaka yaitu dengan mengakses buku dan jurnal budaya yang berkaitan dengan akulturasi, tata rias Sunda Siger dan Igari Look.

Selain itu, peneliti melakukan internet searching untuk mengumpulkan data. Internet searching merupakan salah satu dari produk perkembangan teknologi manusia melalui browser untuk mencari informasi, referensi berupa data dan gambar yang mendukung penelitian yakni melalui situs resmi dari bridestory.com sebagai market place online untuk keperluan pernikahan terbesar di Asia Tenggara jurnal, artikel online yang berkaitan dengan akulturasi, tata rias Sunda Siger juga Igari Look. Peneliti juga menyertakan gambar dari Instagram @ nanathnadia dan @ muthiasalmakh dalam artikel ini sebagai visualisasi teknik Igari Look dalam tata rias Sunda Siger.

\section{HASIL DAN BAHASAN}

Perkembangan ilmu pengetahuan dan teknologi, serta kemajuan dunia usaha dan industri demikian pesat saat ini. Kemajuan ini sangat membutuhkan orangorang profesional di bidangnya masingmasing yang mampu mengenali dan menangkap setiap peluang usaha sebagai konsekuensi logis dari persaingan bisnis yang kian tajam. Seorang penata rias (make-up artist) harus menguasai:

"pengaturan riasan pada pengantin dengan menggunakan kosmetik dan teknik tertentu yang bertujuan untuk merubah ke arah yang untuk melakukannya (tidak tergesa-gesa) agar riasan yang dihasilkan sesuai dengan yang diharapkan" (Pebrianti, 2017: 3).

Selera atau cita rasa estetis dari masyarakat pun tampak berkembang pesat sehingga menuntut para juru rias untuk mengimbanginya dengan daya kreatifitasnya di bidang tata rias pengantin masa kini (Ibrahim dkk, 1984: 4). Jika ditinjau dari sisi promosi, make-up artist dinilai dapat lebih memanfaaatkan teknologi dalam melakukan promosi, (khususnya dengan menggunakan Instagram) jika dibandingkan dengan juru rias.

Dalam perkembangan teknologi dewasa ini, rasanya tidak bisa dipungkiri jika Instagram adalah salah satu sarana inspirasi bagi calon pengantin, dalam hal ini nyaris setiap make-up artist memiliki akun Instagram untuk mengunggah portofolio tata rias yang mereka hasilkan. Kemudahan akses untuk mengetahui informasai mengenai tren tata rias terkini menjadi pendorong utama lahirnya makeup artist berbakat di tanah air. Di masa kini, popularitas sekaligus penghasilan para make-up artist menjadi profesi yang menggiurkan.

Tata rias Sunda Siger merupakan keindahan sakral yang mengandung nilainilai luhur budaya. Tata rias merupakan sistem kesenian yang merupakan salah satu kebudayaan universal yaitu sebagai 
"sistem kesenian yang merupakan sarana yang digunakan untuk mengekspresikan diri pada keindahan" (Syarbaini dan Rusdiyanta, 2008: 103).

Tata rias Sunda Siger merupakan bagian dari kebudayaan Sunda yang berkaitan dengan konstruksi kecantikan khas Sunda.

"Dalam sebuah tata rias pengantin tradisional biasanya dibentuk atas dasar budaya, legenda dan mitos yang berlaku di daerah tersebut, serta kondisi-historis masyarakat, mengingat pada dasarnya tata rias pengantin merupakan wujud kebudayaan yang berdasar pada ide, gagasan dan filosofi yang diwujudkan dalam hasil karya manusia" (Ningtyas dan Faidah, 2013: 39).

Adapun kecantikan khas Sunda menurut ${ }^{3}$ Konsep Kageulisan Mojang Sunda" yaitu"

1. Rambut hideung meles, galing muntang, ombak banyu (rambut hitam berkilau, keriting dan bergelombang)

2. Pameunteunna ngadaun sereuh (bentuk wajahnya seperti daun sirih)

3. Taar teja mentrangan (kening terang bersinar)

4. Halis ngajeler paeh (alis seperti ikan jeler mati)

5. Soca cureuleuk, bulu soca carentik (mata berbinar, bulu mata lentik)

6. Damis ngagula sapasi sapertos katumbiri (pipi setengah gula seperti pelangi)

7. Pangambung uwung-uwungan

8. Gado ngendog sapotong/sapasi (dagu seperti telur separuh/setengah)

9. Lambey jeruk sapasi (bibir setengah jeruk)

10. Waos gula gumantung (gigi bergelantung gula)

\footnotetext{
${ }^{3}$ Disampaikan oleh Prof. Dr. Endang Caturwati dalam Pengantar Saresehan Budaya , "Upacara Adat Mapag Panganten Sunda Perubahan Nilai dan Makna”, 27 September 2018
}

Dalam konteks ini, akulturasi dalam tata rias Sunda Siger yang merupakan bagian dari budaya Sunda yang berbaur dengan Igari Look yang merupakan teknik dalam tata rias modern dari negeri Jepang, yang biasa digunakan para aktris drama ataupun para girl band Jepang. Sampainya tren Igari Look dalam kebudayaan Sunda membuktikan bahwa "Jepang memiliki budaya populer yang sangat kuat isi dibandingkan dengan budaya populer Indonesia yang mengambil bagian dari berbagai negara lewat media-media mereka (drama, musik dan buku)" (Safariani, 2017: 11).

Kekuatan Jepang dalam menyebarkan budaya populernya hingga dapat berakulturasi dengan kebudayaan Sunda menggambarkan bahwa Jepang adalah negara maju yang sangat militan untuk mengekspor budayanya. Penyebaran budaya tersebut merupakan bagian dari soft power diplomacy, yaitu diplomasi melalui budaya yang merupakan aktualisasi dari penggunaan instrumen budaya dalam kegiatan diplomasi.

Jika dilihat dari sejarahnya, Jepang memang selalu ingin tampil maksimal dalam mengembangkan kemampuan dan kekuatan negaranya untuk mengekspor segala jenis teknologi dan budaya populernya. "Keadaan inilah kiranya yang mendorong dan membudayakan kreativitas orang Jepang, termasuk kreativitas menciptakan segala macam perlengkapan hidup yang lebih dari sekadar kebutuhan tetapi lebih pada kenyamanan, sehingga kreativitas berproduksi selalu berkembang" (Sartini, 1999: 2).

Produk-produk budaya ini menonjol dengan dua sifat, yakni bersifat Jepang dan diterima secara universal di antara kaum muda, di mana Kementrian Luar Negeri Jepang bekerjasama dengan sektor swasta melalui jalur diplomasi dan Japan Foundation, bersama-sama mempromosikan produk-produk budaya untuk meningkatkan citra dan minat terhadap Jepang" (Priendarningtyas, 2012: 5). Aktivitas produksi yang dilakukan 
Jepang tidak selalu berkutat dalam dunia teknologi dan manufaktur. Jepang dianggap produktif dalam memroduksi dan mendistribusikan budaya populernya ke seluruh dunia, salah satunya adalah Igari Look yang dibawa melalui budaya idol dan drama Jepang. “

Kemudahan dalam mengakses budaya populer Jepang di Indonesia disebabkan karena Jepang berhasil membangun budaya popular dan menyebarkannya sampai ke Indonesia, salah satunya dengan kebijakan pemerintahan Jepang "untuk meningkatkan kesan positif Jepang melalui promosi kebudayaan, pariwisata, perdagangan maupun kuliner" (Kusumah,2017:21) Akulturasi antara Igari Look dan tata rias Sunda Siger dipahami sebagai konsekuensi masuknya budaya populer Jepang melalui perkembangan informasi dan teknologi. Pengaruh budaya popular tersebut menghasilkan inovasi dalam sebuah tata rias, yang pada hakikatnya tetap ingin menonjolkan sisi kecantikan khas perempuan Sunda. Dalam konteks ini akulturasi dinilai sebagai hasil inovasi yang membuat suatu tata rias tradisional digemari, dengan ditambahkannya nuansa modern dan kreatif.

Akulturasi antara kebudayaan Jepang dan Sunda yang terlihat pada tata rias Sunda Siger tersebut merupakan bukti bahwa masyarakat Sunda merupakan masyarakat yang terbuka dengan situasi multikultural. Tata rias Sunda Siger merupakan tata rias pengantin yang bersifat sakral dapat dieksplorasi dengan penggunaan teknik Igari Look yang biasa digunakan para aktris drama ataupun para girl band cenderung santai, fun dan natural. Dalam hal ini terjadi perubahan bahwa tata rias Sunda Siger yang terkesan kaku, berat dan sarat akan warna yang mencolok, kini telah memasuki era tata rias yang mengutamakan sisi flawless dan soft.

Masuknya era tata rias flawless dan soft dalam tata rias Sunda Siger, tidak bisa dipisahkan dengan adanya pengaruh tren tata rias Korea Selatam yang sedang booming di kalangan beauty enthusiast di Indonesia. Korea Selatan dapat dikatakan sebagai kiblat tren tata rias di wilayah Asia. Namun yang perlu diketahui bahwa tren penggunaan blush-on di bawah mata yang kini menjadi tren di Korea Selatan (kini perempuan Indonesia juga kerap menggunakan teknik tersebut) merupakan teknik tata rias dari Jepang.

Jepang dan Korea Selatan memiliki kemiripan gaya tata rias karena sama-sama menonjolkan sisi natural dan menjauhi kesan berat. Dalam setiap tampilannya, Igari Look yang merupak tren tata rias dari Jepang kini menjadi tenik tata rias yang juga booming di daerah Korea Selatan. Banyak orang yang salah kaprah dan menilai teknik penggunaan blush-on di bawah mata sampai area pipi adalah teknik tata rias Orang Korea Selatan, padahal Jepang sudah lebih dulu menciptakannya.

Pengaruh Jepang dalam tren tata rias di Indonesia, tidak terlepas dari banyaknya hiburan, seperti musik serta drama Jepang yang masuk ke Indonesia. Drama-drama tersebut menyuguhkan tampilan wajah para aktris yang lembab, bersinar, sehat dan natural dengan penggunaan warnawarna tata rias yang cenderung mengarah pada warna-warna seperti pink dan orange.

Secara tidak sadar, ketika penonton menyaksikan hiburan dari Jepang, penonton bukan hanya mengonsumsi cerita dari drama yang ditampilkan, namun turut serta mengonsumsi budaya dari Jepang. Nadia Sabrina @nanathnadia sebagai make-up artist yang mengadopsi Igari Look dalam signature (ciri khas) tata riasnya mengakui bahwa dirinya terinspirasi dari drama Korea yang menampilkan aktris dengan tampilan yang natural dengan teknik blush-on Igari Look, yang mana sebetulnya Igari Look diciptakan di negeri Jepang.

Melalui menonton drama, ternyata dapat membangkitkan semangat inovasi yang diaplikasikan sebagai keterampilan merias pengantin. Hal ini dapat diapresiasi untuk menjadi upaya dalam 
mempertahankan budaya daerah, agar tata rias tradisional tetap lestari dan hidup. Di sisi lain, menjadi tanggung jawab sang make-up artist untuk bisa menyesuaikan diri dengan perkembangan tata rias. Dalam konteks ini, setiap make-up artist dituntut untuk selalu berinovasi. Inovasi dapat dimaknai sebagai upaya mengembangkan keterampilan tata rias untuk mendapatkan tampilan atau teknik yang baru dengan tujuan menambah nilai estetika dalam kreasi tata rias.

Pada hakikatnya, kreativitas dan inovasi yang ditampilkan dalam tata rias komersial merupakan sebuah pengembangan dari tata rias yang sesuai pakem, mengingat inovasi dan signature (ciri khas) merupakan salah satu upaya untuk menaikan "unique selling point" seorang make-up artist agar dapat terus berkembang sesuai keinginan pasar dan trend tata rias (Wawancara dengan Eviyawati 10 Mei 2018).

Dalam hal ini, setiap ada penggabungan budaya baru dalam konteks tata rias, maka akan selalu polemik "melanggar pakem". Pada dasarnya setiap jenis tata rias pengantin tradisonal sudah memiliki pakem yang telah dibakukan.

"tata rias pakem atau asli adalah cara yang digunakan pemuka adat (sesepuh kita), sementara tata rias modifikasi adalah merupakan cara yang meningkatkan pengetahuan perias dalam merias tanpa menghilangkan unsur aslinya (Puspita Martha International Beauty School, 2010: 10)

Tugas penting bagi para make-up artist yang menangani tata rias Sunda Siger adalah tetap melakukan inovasi. Namun demikian, tidak serta merta menghilangkan unsur tradisional dalam tata rias Sunda Siger. Akulturasi bukan merupakan penggabungan dua budaya yang serta merta dilakukan tanpa sebuah kompromi karena dikhawatirkan justru akan merusak budaya tradisonal, perlu dilakukan seleksi dalam "menyaring donor budaya sesuai dengan kebutuhan, baik secara subjektif, maupun secara objektif" (Sachari, 2007: 30). Oleh karena itu diperlukan tahap seleksi dalam sebuah akulturasi, di mana dalam tahap seleksi inilah kebudayaan yang datang dipilih dengan pertimbangan yang matang. Begitupun dalam akulturasi budaya Jepang dan Sunda melalui Igari Look dalam bingkai tata rias Sunda Siger, perubahan dalam tata rias tidak bersifat mayor, titik perubahan yang paling dominan adalah dengan memindahkan titik berat kemerahan yang tadinya di tulang pipi menjadi di bawah mata untuk tampilan pengantin yang lebih segar.

Dapat dikatakan bahwa Igari Look dalam tata rias Sunda Siger merupakan hasil rekonstruksi budaya baru yang hadir atas bantuan dan tuntutan teknologi. Bentuk rekonstruksi selalu berkonsentrasi pada kondisi sosial dan budaya melalui sains, teknologi dan industri atas sesuatu hal yang lebih cocok untuk kondisi dan kebutuhan manusia, dalam konteks ini Igari Look dinilai sejalan dengan apa yang dibutuhkan pengantin wanita Sunda Siger di masa kini yang mengutamkan sisi flawless dan soft dalam sebuah tampilan tata rias.

Dalam tata rias Sunda Siger, Igari Look memiliki titik berat pada penggunaan blush-on di bawah mata. Ada perbedaan pendapat dalam menyikapi penggunaan Igari Look dalam tata rias Sunda Siger. Make-up artist generasi milenial (kelahiran 1980-1997) menganggap bahwa tata rias Sunda Siger dinilai tidak melanggar pakem tata rias Sunda karena make-up artist hanya memindahkan titik berat kemerahan yang tadinya di tulang pipi menjadi di bawah mata untuk tampilan pengantin yang lebih segar (Wawancara dengan Muthia pada 13 April 2018).

Namun, di sisi lain, make-up artist senior menganggap bahwa Igari Look dalam tata rias Sunda Siger tidaklah sesuai pakem tata rias Sunda Siger yang telah dibakukan, mengingat pakem adalah hal yang tidak bisa diubah. Dalam konteks ini berkarya dalam tata rias komersial, nyaris 
tidak ada yang benar-benar sesuai pakem, semua make-up artist bebas berekspresi dan berinovasi dalam tata rias.

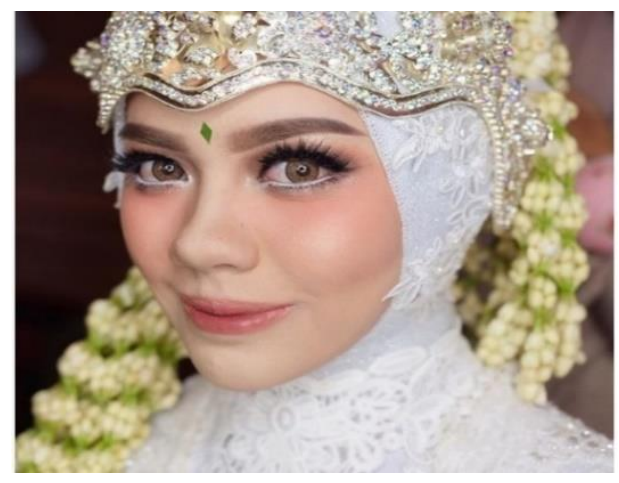

Gambar 2

Penggunaan teknik blush-on Igari Look pada tata rias Sunda Siger

Sumber: Instagram @nanathnadia

Tata rias sesuai pakem menurut Eviyanti, pada saat ini digunakan hanya diaplikasikan pada uji kompetensi yang diujikan pada warga belajar di sebuah Lembaga Pelatihan Kerja yang mengambil keahlian tata rias Sunda Siger (Wawancara dengan Eviyawati, 10 Mei 2018). Adapun materi yang diujikan adalah "konsep dasar tata rias pengantin, macam-macam jenis gaya riasan, teknik tata rias, teknik pemasangan aksesori rambut, prosesi pernikahan adat Sunda " (Nurhasan, 2014: 2 ), sementara tata rias komersial adalah sebuah tata rias modifikasi yang saat ini digunakan untuk pernikahan. Dari konsep tersebut sudah jelas bahwa penggunaan tata rias untuk pengantin tergolong pada tata rias komersial yang di dalamnya terdapat proses kreatif dari kreator tata rias (make-up artist) dimana ide kreatif tersebut pada akhirnya akan menjadi "nilai jual" pada tata rias dan mendatangkan pundi-pundi uang sebagai sebuah mata pencaharian.

Igari Look dalam tata rias Sunda Siger dapat dimaknai sebagai kreativitas, namun di sisi lain Igari Look juga dapat diartika sebagai suatu komodifikasi budaya. "Komodifikasi merupakan bentuk transformasi dari hubungan yang awalnya terbebas dari hal-hal yang sifatnya diperdagangkan, menjadi hubungan yang sifatnya komersil" (Ajidarma, 2016: 154). Tata rias Sunda Siger seolah ditumpangi dalam sebuah kepentingan industri tata rias yang melunturkan identitas budaya Sunda itu sendiri, guna melancarkan persaingan bisnis make-up artist yang dalam hal ini akan sekuat daya untuk berlomba menciptakan dan melanggengkan signature (ciri khas) tata rias yang dimilikinya untuk menciptakan identitas pribadi dengan naiknya pengikut di Instagram sehingga akan menaikan reputasi sang make-up artist.

Adorno dan Horkheimer (1979: 123) mengatakan bahwa media telah memiliki kemampuan untuk menghasilkan industri budaya yaitu budaya yang sudah mengalami komodifikasi karena produk yang dihasilkan tidak otentik, dimana kebudayaan yang diproduksi secara otonom atau murni tidak dihasilkan oleh rakyat atau masyarakat yang memilikinya, akan tetapi ada campur tangan industri dengan segala sistem pasar dan produksinya. Benda budaya yang dipenuhi dengan nilai-nilai tinggi otentik dan kebenaran telah mengalami pergeseran makna.

Polemik "pakem" dalam pengaplikasian Igari Look dalam tata rias Sunda Siger pada hakikatnya adalah hal yang biasa terjadi, mengingat selalu ada perbedaan pendapat apabila budaya tradisional dikaitkan dengan budaya modern. Dalam konteks ini pakem di dalam tata rias Sunda Siger dihadapkan dengan tuntutan industri tata rias yang menuntut para make-up artist pada suatu kepentingan ekonomi. Para make-up artist mau tidak mau harus sigap membaca tren tata rias yang disukai oleh para calon pengantin agar tata rias yang dikreasikannya tetap laku di pasaran.

Sebuah akulturasi budaya tata rias akan membawa kita pada perdebatan mengenai idealisme dalam mempertahankan budaya asli dan kebutuhan ekonomi yang mengharuskan 
adanya pergerakan ke arah modern guna tetap menghidupkan budaya agar relevan dengan zaman. Pada akhirnya perdebatan tersebut akan bermuara pada "sebuah upaya kapitalisme dalam budaya". Ida (2014: 4) sebagaimana ia mengutip Stuart Hall, menyebutkan bahwa:

"kajian budaya selama ini fokus pada ekonomi industrialisasi modern dan budaya media yang terorganisir dalam garis kapitalis. Representasi kemudian dilihat sebagai hasil produksi atau korporasi yang diatur dan diarahkan oleh motif atau orientasi profit atau keuntungan".

Apa yang diungkapkan Stuart Halll pada dasarnya sangat relevan dengan konteks akulturasi antara tata rias tradisional dan modern. Hal tersebut menjadi suatu keniscayaan di era ekonomi global yang tumbuh karena ada "permintaan pasar". Tata rias tradisional kini, bukan lagi hanya sebagai seni mempercantik wajah yang sarat akan budaya luhur peninggalan nenek moyang dengan nilai estetik yang dilandasi makna filosofis dari setiap unsurnya.

Dalam tata rias tradisional Sunda Siger yang sesuai pakem alat-alat yang dipergunakan adalah:

"gincu (pemerah bibir). Celak (penghitam alis), pupur (bedak untuk penjernih kulit khususnya kulit muka), mangir (bedak bobok untuk penghalus kulit secara menyeluruh , khususnya tubuh lengan dan kaki). Alat-alat tersebut adalah alat-alat yang diciptakan dari bahan-bahan alam, atau dapat dikatakan diciptakan secara tradisional" (Caturwati, 1997:6)

Selain itu, riasan wajah dalam tata rias Sunda Siger memiliki tata aturan dalam penanganan tata rias Sunda Siger :

"Pada zaman itu, sebelum calon penganti perempan didandani, wajahnya dibersihkan dengan air hangat. Setelah bersih dipulaskan bedak asam, saripohaci, atau atal yang warnanya kekuning-kuningan. Alisnya dibentuk dengan cara dikerik. Untuk yang beralis tipis atau gundul, perias menggunakan rengasu yang dibuat dari arang dapur atau dari hasil kerikan bawah teko. Arang tersebut lalu dicampurkan dengan sedikit minyak kelapa, dan dioleskan pada alis. Para calon mempelai pun diminta untuk mengunyah sirih agar pada hari pernikahannya bibir menjadi merah. Selain mengunyah sirih, mempelai perempuan menggunakan buah galinggam sebagai pemerah bibir. Minyak pale digunakan untuk mengilatkan bibir (Giadi, 2010)"

Alat-alat dan cara menggunakan tata rias tersebut nampaknya sangat sulit jika diaplikasikan di masa kini. Sebabnya, teknologi tata rias semakin hari semakin diperbaharui untuk semakin canggih dari sisi pigmentasi, ketahanan dan ragam warna yang akan terus bertambah jenisnya seiring perjalanan tren tata rias. Jika sang make-up artist mempertahankan dengan ajeg penggunaan alat-alat tata rias tradisional, dikhawatirkan akan terlihat rawan dari sisi pigmentasi, ketahanan dan ragam warna karena alat tata rias tradisional yang alami kurang menjanjikan pigmentasi, serta ketahanan dan ragam warna yang mumpuni. Selain itu, make-up artist Sunda Siger di masa kini dituntut untuk tidak melakukan banyak touch-up (perbaikan tata rias untuk menjaga tampilan agar selalu optimal) mengingat tidak ada waktu untuk banyak touch-up karena rangkaian acara pernikahan dari akad sampai resepsi biasanya mengundang ribuan orang untuk bersalaman yang memakan waktu hingga seharian penuh. Alat-alat tata rias modern dapat "mengamankan dengan baik" tampilan pengantin dari sisi pigmentasi, ketahanan dan ragam warna.

Tata rias kini, bukan hanya seni yang syarat makna serta simbol ketradisian tetapi berubah dalam makna ekonomi. 
Setiap pelaku industri baik itu perusahaan kosmetik dan para make-up artist berlomba-lomba menciptakan tren dan signature (ciri khas) dalam tata rias, termasuk salah satunya dengan menghidupkan tata rias tradisional dengan sentuhan modern. Industri tata rias Indonesia di tahun 2018 mengalami kenaikan pertumbuhan $20 \%$ atau empat kali lipat dari pertumbuhan ekonomi nasional pada tahun 2017, hal itu membuktikan bahwa Indonesia adalah pangsa pasar yang baik untuk sebuah industri tata rias ${ }^{4}$.

Keberadaan Igari Look dalam bingkai tata rias Sunda Siger pada hakikatnya bukan bertujuan untuk memarjinalkan makna filosofis dan historis dalam setiap unsur tata riasnya. Dalam setiap akulturasi yang melibatkan proses inovasi make-up artist ini merupakan sumbangsih mereka untuk menghidupkan kembali tata rias tradisional agar para perempuan Sunda memiliki kebanggan pada saat merias ataupun dirias dengan tata rias Sunda Siger. Dengan demikian, tata rias tradisional Sunda Siger akan tetap berdiri sebagai tren yang selalu dipilih para perempuan Sunda di hari pernikahannya. Di samping itu, ada motif profit ekonomi bagi para make-up artist untuk turut serta mencari peruntungan dalam dunia tata rias.

Namun yang perlu digaris bawahi adalah motif orientasi profit atau keuntungan dalam konteks ini tidak serta merta merusak budaya dari tata rias Sunda itu sendiri, mengingat tata rias Sunda Siger yang mengalami proses akulturasi dengan Igari Look tetap mempertahankan sisi identitas perempuan Sunda. Dalam konteks ini penggunaan Siger di kepala pengantin perempuan sebagai kehormatan, meletakkan kearifan, serta sikap bijak sebagai hal pokok yang perlu dijunjung tinggi sebagai bakti istri kepada suami. Hal tersebut merepresentasikan budaya patriarki yang tumbuh dalam budaya

\footnotetext{
${ }^{4}$ http://www.kemenperin.go.id/artikel/18957/In dustri-Kosmetik-Nasional-Tumbuh-20 diakses pada 29 Mei 2018 pada pukul 10.10 WIB
}

Sunda, yang menempatkan suami pada posisi paling tinggi dalam sebuah kehidupan rumah tangga.

Identitas dijadikan sebagai tanda pengenal, memiliki makna pada budaya yang diciptakan oleh masyarakat tersebut, sehingga bisa dibedakan antara satu kebudayaan dengan kebudayaan lainnya.

"Kalau kita ingin mengetahui dan menetapkan identitas budaya maka kita tidak sekadar menentukan karakteristik atau ciri-ciri fisik atau bilogis semata-mata, tapi mengkaji identitas kebudayaan sekelompok manusia melalui tatanan berpikir (cara berpikir, orientasi berpikir), perasaan (cara merasa dan orientasi perasaan) dan cara bertindak (motivasi tindakan atau orientasi tindakan)" (Liliweri, 2007:72).

Dalam hal ini, masyarakat Sunda memiliki karakter siger tengah yang bermakna bahwa hidup harus mengutamakan kontrol keseimbangan terlebih dalam sebuah kehidupan pernikahan, agar hidup tetap dalam kewajaran (tidak terlalu kiri, tidak terlalu kanan, namun berada di tengah). Pada dasarnya karakter melekat pada suatu kebudayaan akan membentuk juga karakter individu. Tata rias Sunda Siger dalam hal ini, merupakan suatu karakter budaya Sunda yang dimiliki masyarakat Sunda, yang berisi harapan guna mendapat kehidupan pernikahan yang harmonis.

Bentuk-bentuk yang terdapat pada tata rias Siger Sunda adalah bentuk ekspresi dan penyampaian suatu nilai budaya. Meskipun terdapat proses akulturasi yang terpengaruh Igari Look, namun pada hakikatnya tidak mengubah hal-hal krusial yang menjadi identitas budaya Sunda. Adapun pengaruh Igari Look dalam tata rias Sunda Siger dijelaskan sebagai berikut: 


\section{Bentuk Akulturasi Tata Rias Sunda Siger yang Terpengaruh Igari Look \\ a. Riasan Mata}

Dalam tata rias Sunda Siger sesuai pakem penggunaan eyeshadow biasanya menggunakan sapuan warna hijau, coklat dan kuning, namun penonjolan warna hijau harus lebih dominan dibanding warna lain. Dalam tata rias Sunda Siger yang mengusung Igari Look biasanya penggunaan eyeshadow menggunakan warna coklat tua, coklat muda dan emas, warna tersebut dinilai hangat dan cocok untuk segala warna kulit. Mengusung warna coklat juga memudahkan make-up artist untuk meringkas waktu kerja, mengingat riasan mata berwarna coklat cocok digunakan, baik pada saat akad maupun saat resepsi pernikahan, sehingga para make-up artist hanya perlu mengganti warna lipstick untuk menambahkan kesan dan suasana berbeda pada wajah pengantin.

Riasan mata dengan eyeshadow warna coklat tua, coklat muda dan emas juga akan lebih menyatu dengan teknik blush-on Igari Look. Selain itu, penggunaan eyeliner putih, silver dan emas di bawah mata sering digunakan untuk menambah tampilan segar, berkilau dan membuat kesan mata yang lebih besar. Teknik penggunaan eyeliner putih, silver dan emas di bawah mata dinilai sangat cocok jika dipadukan dengan teknik Igari Look disebabkan, di negeri asalnya Jepang, Igari Look selalu dipadukan dengan penggunaan teknik riasan mata agar mata terlihat lebih besar, namun tetap dalam kesan riasan yang tidak berat. Salah satu caranya adalah membubuhkan eyeliner putih, silver ataupun emas yang semakin menegaskan kesan natural, segar dan ringan di wajah, namun tetap memiliki aksen modern dan berwarna. Dalam hal ini Igari Look jika dipadukan dengan riasan mata yang nyentrik justru akan mengaburkan kesan natural, segar dan ringan yang menjadi ciri khasnya.

\section{b. Riasan Wajah}

Keberadaan tata rias sesuai pakem sepertinya sudah jarang, atau bahkan tidak mungkin digunakan dalam tata rias pernikahan di masa kini. Pada hakikatnya tata rias sesuai pakem dewasa kini, hanya digunakan untuk Ujian Kompetensi yang diujikan di Lembaga Pendidikan Keterampilan (LPK) (Wawancara dengan Eviyawati, 10 Mei 2018).

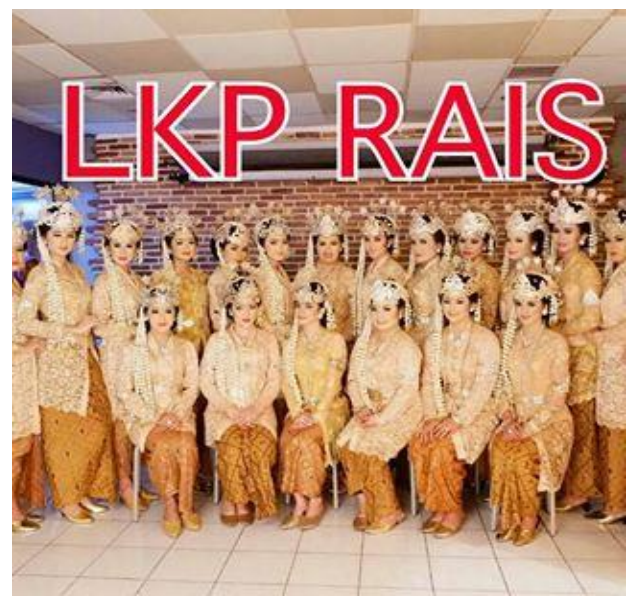

Gambar 3

Contoh tata rias pakem dalam Lembaga

Pendidikan Keterampilan Sumber: LKP RAIS

Tata rias sesuai pakem pada dasarnya adalah tata rias yang digunakan pemuka adat (sesepuh) di zaman dahulu yang memiliki makna filosofis dan historis dalam setiap unsur tata riasnya. Saat ini tata rias sesuai pakem diadopsi menjadi sebuah kurikulum yang menjadi standar kelulusan untuk pendidikan keterampilan tata rias di Lembaga Pendidikan Keterampilan (LPK).

Dapat dikatakan bahwa tata rias sesuai pakem merupakan modal dasar bagi make-up artist. Tata rias sesuai pakem menjadi pijakan awal untuk menjajaki industri tata rias Sunda Siger, di mana setelah lulus Ujian Kompetensi, para make-up artist tersebut akan memasuki dunia tata rias komersial yang memiliki kebebasan untuk melakukan proses kreatif. Salah satunya dengan menggunakan Igari Look dalam teknik membubuhkan blush- 
on. Penggunaan lipstick merah dengan tekstur creamy yang merupakan pakem tata rias Sunda Siger pun sudah mulai terganti dan dimodifikasi.

Pada awalnya penggunaan warna merah sebagai warna lipstick sesuai pakem karena pada zaman dahulu hanya ada sirih untuk memerahkan bibir, maka dari itu pengantin dianjurkan "mengunyah sirih agar pada hari pernikahannya bibir menjadi merah. Selain mengunyah sirih, mempelai perempua menggunakan buah galinggam sebagai pemerah bibir. Minyak pale digunakan untuk mengilatkan bibir“ (Giadi, 2010). Adanya budaya mengunyah sirih merupakan cikal bakal penggunaan lipstick merah sebagai warna pakem dalam tata rias Sunda Siger.

Namun demikian, saat ini banyak faktor yang memengaruhi pemilihan warna lipstick bagi pengantin Sunda Siger yang tidak hanya melulu menggunakan warna merah. Misalnya warna lipstick disesuaikan dengan warna kulit, bentuk bibir, kesesuaian dengan warna kebaya, kesesuaian dengan konsep acara pernikahan, ataupun justru pengantin dan make-up artist memiliki pilihan warna kesukaan tersendiri yang menjadikan dasar pijakan pemilihan lipstick.

Dari pemaparan di atas terlihat banyak faktor yang menjadi pertimbangan pemilihan warna lipstick yang bersifat subjektif. Namun, pada dasarnya warna lipstick dalam tata rias Sunda Siger dapat dikelompokan dalam tiga kelompok besar yaitu: (1) nude lipstick dengan sapuan warna yang mengarah ke coklar, natural lipstick yang mengusung dengan sapuan warna yang mengarah ke pink, (3) bold lipstick dengan sapuan warna yang mengarah ke merah.

Saat ini ada tren lipstick terbaru dalam tata rias pengantin yakni penggunaan lipstick ombre (lipstick gradasi), yaitu penggunaan dua warna sekaligus yaitu warna natural atau nude yang ditambahkan dengan warna bold di bagian dalam bibir (Wawancara dengan Eviyawati, 10 Mei 2018). Riasan lipstick ombre (lipstick gradasi) memberikan kesan muda dan cerah pada tampilan wajah, di samping itu penggunaan lipstick ombre memberikan kesan bibir lebih bervolume.

Pakem tata rias Sunda Siger menggunakan bedak yang bersemu kuning atau zaman dahulu dikenal dengan wedak bangkuang pada wajah pengantin.

"Kulit muka yang dibedaki dengan piranti kecantikan yang dianggap berasal dari Sanghiang Sri, besar kemungkinan dengan tujuan agar sang pengantin dapat memancarkan paras muka Sanghiang Sri itu sendiri” (Departemen Pendidikan dan Kebudayaan, 1986: 90).

Penggunaan bedak berwarna kuning tersebut sudah ditinggalkan karena sekarang bedak dan foundation justru mengikuti warna kulit pengantin perempuan. Oleh karena warna kulit yang cenderung coklat, kuling langsat, sawo matang dan putih tidak bisa dipukul rata dengan menggunakan bedak dan foundation berwarna kuning. Ditambah dalam Igari Look justru tone warna kulit wajah menjadi bersemu warna pink dan orange bukan bersemu kuning. Hal tersebut disebabkan blush-on yang dibubuhkan terhitung luas cakupannya, yaitu dari bawah mata sampai tulang pipi.

Dari segi korektif, blush-on dengan teknik Igari Look bisa menutupi kantong mata, kerutan mata dan lingkarang gelap di bawah mata. Hal tersebut sejalan dengan prinsip tata rias "menonjolkan kelebihan dan menutupi kekurangan". Penggunaan blush-on dengan teknik Igari Look cocok untuk segala bentuk wajah, mengingat penggunaannya tidak dibubuhkan di bawah tulang pipi, melainkan berada di bawah mata. Hal ini dapat digunkan untuk menutupi kekurangan di bawah mata, bukan untuk menonjolkan tulang pipi agar terkesan naik, sehingga penonjolan tulang pipi diganti dengan teknik shading.

Penggunaan blush-on yang terlalu pekat dan mencolok pada Igari Look yang diaplikasikan pada tata rias Sunda Siger 
pun tidak dianjurkan dalam keadaan yang terlalu pekat (Wawancara dengan Muthia, 13 April 2018). Penggunaan blush-on yang terlalu pekat disekitar mata dikhawatirkan akan membuat wajah pengantin terlihat seperti sakit mata, maka penggunaannya harus tepat dan tidak berlebihan (Wawancara dengan Mya, 14 April 2018).

Dari segi estetika, blush-on dengan teknik Igari Look dinilai menambah kesan segar pada wajah pengantin. Di samping itu, sapuan warna pink dan orange pada blushon dengan teknik Igari Look di bawah mata juga seolah memberikan kesan alami, karena letak kemerahan pada wajah secara natural terletak dibawah mata, bukan di tulang pipi (Wawancara dengan Muthia pada 13 April 2018).

Teknik Igari Look pun dapat diaplikasikan dalam tata rias pernikahan akad dan resepsi, disebabkan tampilan blush-on Igari Look dapat dipadupadankan dengan berbagai warna lipstick. Biasanya dalam suasana akad, Igari Look dalam tata rias Sunda Siger dipadukan dengan sapuan lipstick warna nude dan natural untuk kesan sakral dan tenang. Sementara dalam suasana resepsi biasanya blush-on Igari Look dipadukan dengan lipstick yang lebih bold seperti merah, pink fuschia ataupun lipstick ombre (gradasi).

Penggunaan daun sirih di tengahtengah dahi disebut diseureuhan.

"Bunyi kata seureuh 'sirih' dianggap berdekatan dengan bunyi kata reureuh 'istirahat' . Karena itu diseureuhan diartikan pangreureuhan, maksudnya ialah seorang istri harus dapat menjadi pangreureuhan (peristirahatan), lebih jauh dapat ditafsirkan bahwa seorang istri harus mampu memberikan keteduhan pada suami dan anak-anaknya" (Wibisana dkk., 1984: 31).

Penggunaan daun sirih juga menjadi simbol penolak bala. Dalam tata rias yang terpapar Igari Look, penggunaan daun sirih ini tidak ditinggalkan.
Pembentukan alis pada dasarnya mengikuti bentuk wajah dari pengantin perempuan. Bentuk alis yang tidak sesuai akan membuat penampilan pada wajah terlihat tampak kurang menarik, bisa jadi terkesan sedih apabila alis terlalu turun atau terkesan galak apabila alis terlalu naik. Disamping itu, pada Igari Look pembentukan alis biasanya mengikuti signature (ciri khas) dari make-up artist; ada yang membubuhkan alis dengan tebal dan lurus layaknya gaya alis Jepang dan Korea, ada juga yang membubuhkan alis dengan kesan naik untuk memperkuat karakter mata yang tegas.

\section{c. Penataan Rambut dan Accessories Kepala}

Hiasan kepala berupa Siger menjadi ciri khas pengantin Sunda. Sunda Siger mempunyai benang merah terhadap budaya Sunda yang sakral. Berdasarkan kamus Basa Sunda R. A. Danadibrata, Siger diartikan sebagai mahkota untuk perhiasan di kepala pengantin. Siger menjadi simbol untuk seseorang yang melaksanakan upacara sakral, seperti pernikahan. Selain itu, dapat diartikan sebagai kehormatan, meletakkan kearifan, serta sikap bijak sebagai hal pokok yang perlu dijunjung tinggi. (Santoso: 2010). Siger terbuat dari logam yang dipasang melingkar. Bagian depannya dipasang pada dahi dan bagian belakangnya berada pada belakang kepala

Pada dasarnya bentuk-bentuk yang terdapat pada atribut pengantin Sunda Siger adalah bentuk ekspresi dan penyampaian suatu pesan moral dan budaya. Ekspresi yang berarti pengungkapan atau mengungkapkan, proses menyatakan. Memperlihatkan atau menyatakan maksud, gagasan dan sebuah perasaan. Rias pengantin dengan susunan bunga berbentuk kupu-kupu pada gelung atau sanggul melambangkan kesetiaan 
sang istri kepada suaminya ${ }^{5}$. Lima kembang goyang dipasang menghadap ke depan, sedangkan dua menghadap ke belakang agar sang mempelai terlihat cantik dari segala sisi. Terakhir, ronce melati dengan panjang melewati bahu menjadi simbol kesucian sang pengantin.

Penataan rambut dan accessories perlengkapan yang menempel di kepala dalam tata rias Sunda Siger yang terpapar Igari Look kini telah mengalami proses modifikasi. Bagi pengantin perempuan Sunda Siger yang tidak menggunakan hijab, biasanya akan menggunakan gelung atau sanggul. Gelung atau sanggul memiliki fungsi untuk mempermudah pemasangan Siger agar lebih kuat dan terlihat rapi ketika dipakaikan di bagian kepala pengantin. Beberapa hiasan penting penghias gelung atau sanggul yaitu enam buah kembang tanjung, garuda mungkur, dan tujuh buah kembang goyang masih dipertahankan. Begitupun pada penggunaan roncean bunga yang terdiri dari melati mangle pasung, mangle susun, mangle sisir, panetep, dan mayangsari yang terbuat dari bunga sedap malam.

"Mangle yang dipergunakan untuk menghiasi sanggul memiliki fungsi estetis, yaitu agar pengantin perempuan tampak lebih atau menjadi cantik. Fungsi estetis penggunaan mangle sebagai hiasan sanggul selain untuk memperindah penampilan pengantin perempuan juga untuk mengharumkan rambut. Suntingan bunga pada rambut akan membuat keadaan harum dengan bau yang khas alamiah" (Wibisana dkk, 1984: 25).

\footnotetext{
${ }^{5}$ https:/www.bridestory.com/id/blog/14mahkota-adat-pernikahan-tradisional-indonesia diakses pada 27 November 2017.
}

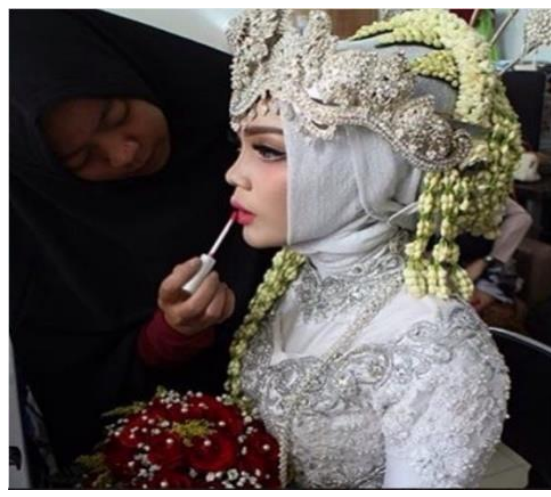

Gambar 4

Muthia sedang melakukan proses tata rias Sunda Siger dengan pengaplikasian Igari Look.

Sumber: Instagram @muthiasalmakh

Kembang tiga dara cengkehan, lima dara yang menghiasi bagian kepala dan menjuntai ke dada pengantin perempuan, masih dipertahankan. Namun, penggunaan giwang atau subang cantik yang menghiasi telinga sudah tidak digunakan, terlebih bagi pengantin Sunda Siger yang berhijab penggunaan giwang atau subang sudah ditinggalkan karena hijab justru sudah menutup bagian telinga. Di sisi lain, Siger yang pada awalnya hanya berwarna emas, kini sudah muncul Siger dengan warna silver dan rose gold.

\section{PENUTUP}

Keberadaan Igari Look dalam bingkai tata rias Sunda Siger pada hakikatnya bukan bertujuan untuk memarjinalkan makna filosofis dan historis dalam setiap unsur tata riasnya. Dalam setiap akulturasi yang melibatkan proses inovasi dari make-up artist ini merupakan sumbangsih mereka untuk menghidupkan kembali tata rias tradisional agar para perempuan Sunda memiliki kebanggan pada saat merias ataupun dirias dengan tata rias Sunda Siger. Dengan demikian, tata rias tradisional Sunda Siger akan tetap berdiri sebagai tren yang selalu dipilih para perempuan Sunda di hari pernikahannya.

Adapun perubahan dalam tata rias tidak bersifat mayor. Perubahan yang paling dominan adalah dengan 
memindahkan nuansa kemerahan yang tadinya di tulang pipi menjadi di bawah mata agar tampilan pengantin menjadi lebih segar. Akulturasi antara kebudayaan Jepang dan Sunda yang terlihat pada tata rias Sunda Siger merupakan bukti bahwa masyarakat Sunda merupakan masyarakat yang terbuka dengan situasi multikultural.

\section{UCAPAN TERIMA KASIH}

Ucapan terima kasih penulis sampaikan rekan-rekan Kajian Budaya Unpad 2017 yang turut serta memberikan masukan dalam jurnal ini. Ucapan terima kasih penulis sampaikan pula kepada informan, yaitu Muthia, Mya dan Ibu Eviyawati, yang sangat terbuka dalam menjawab pertanyaan dari penulis.

\section{DAFTAR SUMBER}

\section{Jurnal, Makalah, Laporan Penelitian, Skripsi, dan Tesis}

Kusumah, Allizia Zulfa . 2017.

Pembentikan Perilaku Konsumerisme Global dan Difusi Budaya Jepang: Studi Kasus Yoshinoya di Bandung. Skripsi Fakultas Hubungan Internasional Universitas Katholik Parahyangan.

Ningtyas, Asmaus Salama Suwita dan Faidah. "Representasi Budaya Tata Rias Pengantin Malang Keputren dan Malang Keprabon". E-Journal Tata Rias Unesa Volume 02 Nomor 01 Tahun 2013.

Nurhasan, Annisa Perbawasari. 2014. Kontribusi Hasil Kursus Tata Rias Pengantin Sunda Siger terhadap Kesiapan Menjadi Penata Rias Pengantin. Skripsi. Fakultas Pendidikan Teknologi dan Kejuruan Universitas Pendidikan Indonesia.

Pebrianti, Yossi. 2017.

Tinjauan tentang Tata Rias Pengantin Koto Nan Gadang di Kota Payakumbuh. Skripsi Fakultas Pariwisata dan Perhotelan Universitas Negeri Padang.

Priendarningtyas. 2012.

Keberhasilan Soft Power Jepang dalam Pengaruh dan Perkembangan Komik Jepang. Skrips Fakultas Ilmu Pengetahuan Budaya Universitas Indonesia.
Safariani, Putri. "Penyebaran Pop Culture Jepang oleh Anime Festival Asia (AFA) di Indonesia tahun 2012-2016" dalam Jurnal Ilmu Hubungan Internasional, 2017.

Sartini. "Nilai-nilai Budaya Jepang: Tinjauan Aspek Nilai Progresif dan Ekspresif Kebudayaan dalam Jepang" dalam Jurnal Filsafat Universitas Gadjah Mada. Vol. 29, Juni 1999.

\section{Buku}

Ajidarma, 2016.

Jokowi, Sangkuni, Machiavelli. Bandung: Penerbit Mizan.

Adorno dan Horkheimer. 1979.

The Culture Industry Enlighment as Mass Deception. London:Verso.

Caturwati. Endang. 1997. Tata Rias dan Busana Tari. Bandung: STSI Press.

Endraswara, Suwardi.2006. Metode, Teori, Teknik Penelitian Kebudayaan. Yogyakarta: Pustaka Widyatama.

Giadi,Reita 2010. Selamanya. Jakarta: Gramedia Pustaka Utama.

Ibrahim, Subandy Idi dan Akhmad. 2014. Komunikasi dan Komodifikasi: Mengkaji Media dan Budaya dalam Dinamika Globalisasi. Jakarta:Buku Obor.

Ida, Rachmah. 2014. Metode Penelitian: Studi Media dan Kajian Budaya.Jakarta: Prenada Media Grup.

Ismayanti. 2010.

Pengantar Pariwisata.Jakarta:Grasindo.

Koentjaraningrat. 1990.

Pengantar Ilmu Antropologi. Jakarta: Universitas Indonesia Press.

Liliweri, Alo. 2007.

Makna Budaya dalam Komunikasi Antarbudaya. Yogyakarta: LkiS.

Sachari, Agus. 2007.

Budaya Visual Indonesia: Membaca Makna Perkembangan Karya Visual di Indonesia Abad ke-20. Jakarta: Penerbit Erlangga. 
Santoso,Tien. 2010.

Tata Rias \& Busana Pengantin Seluruh Indonesia. Jakarta: Gramedia Pustaka Utama.

Wibisana, dkk. 1986.

Arti Perlambang dan Fungsi Tata Rias Pengantin dalam Menanamkan Nilainilai Budaya Daerah Jawa Barat. Jakarta: Departemen Pendidikan dan Kebudayaan Proyek Inventarisasi dan Dokumentasi Kebudayaan Daerah.

Yusuf, Muri. 2017.

Metode Penelitian Kuantitatif, Kualitatif \& Penelitian Gabungan. Jakarta: Penerbit Kencana.

\section{Website}

www.bridestory.com/id/blog/2017-indonesiawedding-trends-report-by-bridestory diakses pada 27 Novermber 2017

www.bridestory.com/id/blog/14-mahkota-adatpernikahan-tradisional-indonesia diakses pada 27 November 2017.

www.Business.bridestory.com diakses pada 7 November 2017.

www.cewekbanget.grid.id/Fashion-And-

Beauty/Tutorial-Igari-Makeup-Riasan-

Cute-Yang-Hits-Banget-Di-Jepang diakses pada 2 Mei 2018.

www.kemenperin.go.id/artikel/18957/IndustriKosmetik-Nasional-Tumbuh-20 diakses pada 29 Mei 2018.

\section{Sumber Lisan/Informan}

Eviyawati (55 tahun). Instruktur senior Sanggar Liza dan Marketing Manager PAC Mazaya Cosmetic. 10 Mei 2018.

Mya (23 tahun). Make-up Artist.. 14 April 2018.

Salma, Muthia Khairunnisa (25 tahun). Makeup Artist. 13 April 2018. 